Working Paper Series

\title{
Divorced in a Flash: The Effect of the
} Administrative Divorce Option on Marital Stability in the Netherlands

Jan Kabátek

Working Paper No. 12/18 November 2018 


\title{
Divorced in a Flash: The Effect of the Administrative Divorce Option on Marital Stability in the Netherlands *
}

\author{
Jan Kabátek ${ }^{1}$ \\ Melbourne Institute: Applied Economic \& Social Research, \\ The University of Melbourne, Australia
}

\section{Melbourne Institute Working Paper No. 12/18 November 2018}

\begin{abstract}
* I gratefully acknowledge funding from the Australian Research Council Centre of Excellence for Children and Families over the Life Course. I would like to thank Murat Iyigun, Phil Morgan, Carol Propper, Kjell Salvanes, Betsey Stevenson, Kees Waaldijk, participants at numerous conferences and seminars, and colleagues at the Melbourne Institute: Applied Economic \& Social Research for helpful comments. The findings and views are my own and should not be attributed to the Melbourne Institute.

${ }^{1}$ Melbourne Institute: Applied Economic and Social Research and ARC Centre of Excellence for Children and Families over the Life Course, University of Melbourne, Melbourne, Australia, Institute of Labor Economics (IZA), Bonn, Germany, CentER, Tilburg University; and Netspar, Tilburg, Netherlands, E-mail: j.kabatek@unimelb.edu.au
\end{abstract}

\author{
Melbourne Institute: Applied Economic \& Social Research \\ The University of Melbourne \\ Victoria 3010 Australia \\ Telephone +61383442100 \\ Fax +61 383442111 \\ Email melb-inst@unimelb.edu.au \\ Website melbourneinstitute.unimelb.edu.au
}

\begin{abstract}
Melbourne Institute: Applied Economic \& Social Research working papers are produced for discussion and comment purposes and have not been peer-reviewed. This paper represents the opinions of the author(s) and is not intended to represent the views of Melbourne Institute. Whilst reasonable efforts have been made to ensure accuracy, the author is responsible for any remaining errors and omissions.
\end{abstract}




\begin{abstract}
Administrative divorce is an optional divorce procedure which allows couples to bypass the court system and dissolve their marriages in a streamlined, uncontested process. The lack of court involvement renders the administrative divorce faster and less expensive than the conventional divorce. In this paper, I investigate whether the administrative divorce option affected the stability of marriages in the Netherlands. Leveraging the ban of the procedure in 2009, I show that the divorce risks were $11.6 \%$ higher under the legal regime which allowed for administrative divorce. This effect is causal, and it exhibits considerable heterogeneity, being stronger among dual-earner couples, native couples, and couples living in rural regions.
\end{abstract}

JEL classification: J12, J18, K36

Keywords: marital stability, divorce, administrative divorce, divorce costs 
Divorce is a costly procedure. Couples around the world allocate large amounts of time and money to dissolve their marriages, spending months in preparation for the divorce hearings and paying thousands for legal representation and other services. For many policy makers, these costs represent an important feature of the marital contract. High costs of divorce are thought to promote marital stability, protecting couples from temporary negative shocks to the enjoyment of their unions. This protective role is well-supported by economic theory (see, e.g., Matouschek and Rasul 2008) however empirical assessments of its practical importance remain challenging.

An obvious problem for studies investigating the relationship between the marital stability and divorce costs is the lack of exogenous variation. Even though the divorce costs are highly variable, their variability is usually confounded with other factors influencing marital stability, such as personal wealth, family composition, or match quality. The empirical literature therefore relies mainly on policy variation, leveraging reforms which have lowered the implicit or explicit costs of divorce. A prime example in this domain is the introduction of unilateral divorce (UD), which allowed spouses to file for a divorce without the consent of their partners. By waiving mutual consent, the UD legislation lowered the transaction costs of divorce, resulting in a pronounced short-run increase of the divorce rate, and small (if any) effects in the long run. ${ }^{1,2}$ However, outside of the domain of the UD legislation, the importance of divorce costs for marital stability remains largely unexplored. This omission is particularly pressing since most developed countries have already adopted the UD legislation, and many have been implementing other legal innovations aimed at making divorce less costly and more accessible.

\footnotetext{
${ }^{1}$ Lower transaction costs under the UD regime are often linked to liquidity constraints or information asymmetries between the divorcing spouses (Matouschek and Rasul, 2008). Chiappori et al. 2015 posit an alternative explanation, showing that the UD effect can also arise due to non-transferable utilities across marital states.

${ }^{2}$ Empirical papers investigating the effects of the UD legislation on marital stability include Peters (1986), Allen (1992), Friedberg (1998), Wolfers (2006), Matouschek and Rasul (2008), and González and Viitanen (2009).
} 
One example of such innovation is the institution of administrative divorce. The administrative divorce is an optional procedure which allows couples to bypass the court system and file for a divorce in a streamlined, uncontested process at the local municipality (or a notary). The procedure is strictly bilateral, which means that the spouses have to be cooperative and consent to this option. The uncontested nature of administrative divorce renders the procedure much faster and less expensive than the conventional divorce, because couples do not have to wait for their court hearings and pay for legal representation.

In this paper I analyse the effects of the administrative divorce option on marital stability in the Netherlands. I do so by exploiting the ban of the so-called 'flash divorce', an administrative divorce option which was available in this country between the years 2001 and 2009. The ban of the policy has several unique and convenient features. First, in contrast to the UD reforms, the ban was not implemented in response to the public demand. The flash divorce option originally emerged as an unintended consequence of another bill, and its ban was implemented in order to restore the legislative status quo. Second, the implementation of the ban was largely unexpected, with the reform announcement preceding its implementation by only 3 months. Third, unlike most reforms of the divorce law, the ban of flash divorce actually increased the costs of divorce. This means that the reform is not subject to "floodgate" effects (i.e., a short-lived surge of divorces following the implementation of a policy which reduces the costs of divorce).

Using administrative data covering all married couples in the Netherlands, I evaluate the relative risks of divorce before and after the ban. The model uses the regression discontinuity (RD) design and shows that the risks of divorce were $11.6 \%$ higher under the policy regime which allowed flash divorce. The RD estimates are validated by a regression discontinuity 
difference-in-differences (RD-DD) model which is estimated using a subsample of couples with children. The control group for the RD-DD model consists of cohabiting couples with children, whose separations were not affected by the changing divorce legislation. The near equivalence of the RD and RD-DD estimates bolsters the evidence that the measured effect is causally attributable to the reform and not to other time-varying processes.

In subsample analyses, I explore heterogeneity in the baseline effect. First, I show that the effect is stronger for two-earner couples with similar wages. The intuition here is that the two-earner couples faced fewer obstacles to an informal divorce settlement, because they were less likely to bargain over alimonies and pension division. Second, the effect is also stronger among middle-income couples and couples living in rural areas, both of whom faced relatively high costs of conventional divorce. Third, the effects are weaker among immigrant couples, due to the legal issues with international recognition of flash divorces.

This paper contributes to the literature documenting the effects of divorce legislation on household decision making. ${ }^{3}$ The key innovation is the focus on a unique policy which has not been analysed before, and which is highly relevant for the current policy debate. Its relevance is demonstrated in several ways. First, the administrative divorce option is a contemporary policy which is being adopted by an increasing number of countries (particularly in the European context). Second, despite its growing availability, the administrative divorce remains highly contentious. Policy makers and legal experts stand divided on its desirability (Aygün 2015), and this division is reflected in the recent decisions to eliminate the administrative option (the

\footnotetext{
${ }^{3}$ In addition to the aforementioned papers focusing on the UD legislation and marital stability, Gruber (2004) evaluates the effects of the UD legislation on children's outcomes; Stevenson and Wolfers (2006) and Brassiolo (2016) investigate the impact on domestic violence, and Delpiano and Giolito (2012) evaluate the impact on crime. Papers investigating other legislative changes include González and Viitanen (2017) who focus on the effects of divorce legalization on children's outcomes, Chiappori et al. (2016) who analyze the impact of changes in alimony laws on household decision making, and Felkey (2011) who considers the implications of covenant marriage reforms.
} 
Netherlands) or to make it less accessible (Denmark). Third, the effects of administrative divorce are relevant for a broader set of reforms of the contemporary divorce law which aim to reduce the costs and the administrative burden embedded in the divorce procedure (other policy instruments in this domain, include the collaborative divorce, mediated divorce or electronic divorce). It needs to be stressed that these recent reforms are distinct from the UD reform, because they are targeted at different types of couples. The UD legislation was targeted primarily at non-cooperative couples who did not agree on the decision to divorce, whereas the more recent policy policy instruments are targeted primarily at couples who are in agreement and who are willing and able to settle their divorces in a cooperative fashion. This contrast of the target groups suggests that the lessons learned from the UD reforms may not be readily applicable for the newer policy instruments - particularly with respect to the post-divorce family outcomes such as domestic violence, or children's cognitive achievement. The variation in the divorce rates identified in this paper can be therefore leveraged to study the effects on other outcomes of interest, and it is likely to provide an interesting contrast to the findings of studies based on the UD introduction.

The rest of the paper is organized as follows. First, I introduce the institutional background and historical context of marriage and divorce in the Netherlands. Second, I introduce the data used for the empirical analysis. Next, I specify the econometric model, and discuss the empirical results. The discussion is followed by concluding remarks.

\section{Institutional Context}

The Dutch experience with administrative divorce is distinct from the experiences of other countries, because the emergence of this divorce option in the Netherlands was not intentional. Administrative divorce for married couples came into existence due to a loophole in 
a same-sex marriage bill passed in April 2001. This caused several idiosyncrasies which will be discussed in detail in this section together with a broader institutional context of marriage and divorce in the Netherlands.

\section{Marriage and divorce in the Netherlands}

The basic principles underlying marriage and divorce in the Netherlands are similar to other developed countries. The commencement of marriage requires a civil wedding procedure which is administered at the local municipality, and the termination of marriage requires a divorce which is processed by the family court system. The default matrimonial property regime is joint (community) ownership. The Netherlands uses a no-fault divorce regime which was introduced in 1971 and replaced the law granting divorce only on grounds of adultery, cruelty or other pre-specified issues (Boele-Woelki et al. 2003). Divorcing couples are required to seek legal representation, and the judicial procedure is initiated by one of the lawyers filing a divorce petition to the court. There is no mandatory separation period, which means that the petition may be filed irrespective of the couple's current living arrangements. Upon receipt of the petition, the judge decides whether a hearing is needed. Court hearings are compulsory for couples with minor children and couples who disagree on the terms of their divorce settlement. If spouses do not object to the submitted divorce settlement, the hearings are typically waived, and the divorce is processed further as uncontested. The divorce takes effect when the court order is entered into the municipal register. The costs of divorce average at approximately $€ 3,000$, however they vary widely, depending on the amount of time spent with lawyers, number of court hearings, and other factors. Legal services for low-income families are heavily subsidized which means that the disadvantaged couples can avoid a large share of the financial costs. 


\section{Registered Partnership}

In 1998, the Dutch government introduced a new type of civil union - registered partnership. Registered partnerships were targeted primarily at same-sex couples, allowing them to enter a formally recognized civil union while keeping marriage for heterosexual couples only (the notion of marriage equality was at that point too controversial). The legal benefits and protections of a registered partnership resemble those of marriage, with one major exception: unlike married couples, registered partners can file for administrative divorce. ${ }^{4}$

The administrative divorce procedure for registered partners consists of three steps. First, the couple is required to pen a mutually agreeable divorce settlement, specifying the details of alimony payments, division of estates, pensions, and child custody. This can be done with or without the assistance of lawyers. Second, the settlement has to be signed by both parties and notarised. Third, the notarised settlement has to be lodged at the municipality. Administrative divorces are strictly uncontested, which means that the settlement terms are not challenged by the municipal officers, and the divorce is effective immediately upon the receipt of the settlement contract. If the registered partners are unwilling or unable to pen a mutually agreeable settlement, they can still file a divorce through the court system.

\section{Same-sex marriage reform and its aftermath}

The access to administrative divorce remained exclusive to registered partners for three years. This changed in 2001 when the Dutch government passed a bill legalizing same-sex marriage. The bill came into effect on April 1, 2001, and it had several consequences for marriages and registered partnerships in the Netherlands. Besides allowing same-sex couples to

\footnotetext{
${ }^{4}$ Waaldijk (2004) mentions two other legal differences between marriage and registered partnership in the Netherlands. Registered partners are excluded from international adoptions, and they do not automatically become legal parents when a child is born to their spouse.
} 
marry, the bill also addressed the transitions between registered partnership and marriage.

Specifically, it allowed registered partners to transform their unions into marriages by means of a simple administrative procedure (couples were required to lodge a request at the municipality and pay a small fee). This procedure was quickly exercised by many same-sex couples who preferred the symbolic value of marriage over that of a registered partnership.

However, the bill also allowed the reverse transitions. To maintain legal symmetry, married couples were allowed to transition into registered partnerships, and they could do so using the same administrative procedure. This feature of the bill proved to have substantial unintended consequences. Unforeseen by policy-makers, the reverse transitions quickly became popular, with many (mostly heterosexual) couples transforming their marriages into registered partnerships. But rather than reflecting their intrinsic preferences for partnerships, these actions were prompted by marital instability. The couples who made the reverse transitions did so in order to dissolve their marriages, engaging in what was termed a 'flash divorce' (flitsscheiding).

\section{Flash divorce}

The reverse transition enabled married couples to switch to the legal regime applicable to registered partners which included the right to dissolve the partnership by means of administrative divorce. There were no other benefits associated with being in a registered partnership, and a vast majority of couples who made the reverse transition immediately followed through with their divorce intentions (Statistics Netherlands records only 9 marriages that have not been dissolved past the reverse transition).

Compared to the conventional divorce, flash divorce was advantageous in three respects. First, it was considerably cheaper. An illustrative comparison of costs embedded in the two divorce procedures is presented in Table 1. The settlement of financial and custodial matters was 
left up to the spouses themselves, and while they were encouraged to seek legal counsel, this was not formally required. These features made the flash option particularly attractive for divorcing couples who felt little to no need for legal mediation.

[Table 1 about here]

Second, flash divorce was considerably faster to process. According to the Dutch divorce websites, conventional divorces take approximately 3 months to settle. This reflects the fact that the courts require a minimum of 6-8 weeks to process the submitted divorce petitions, and the submission itself is preceded by a period during which the couple works with lawyers towards finalizing their divorce settlement. In contrast, flash divorce was not burdened by any statutory processing times, which meant that the couple's decision could become effective immediately upon notarising the divorce settlement. The administrative burden was therefore greatly reduced, and couples could expect to be divorced in a fraction of the time corresponding to the conventional procedure..$^{5}$

Third, flash divorce was more accessible for couples living outside of regional centres. Unlike conventional divorces, which are processed by a small network of 19 regional courts, flash divorces were processed by local municipality offices (there are 390 municipalities in the Netherlands). By opting for a flash divorce, couples could save themselves the costs and time spent on commuting to the courts and law firms. Considering the Dutch geography, these considerations were inessential for the most couples, but they could prove substantive for couples living in rural areas or on the coastal islands.

\footnotetext{
${ }^{5}$ Even when accompanied by legal mediation, flash divorces were advertised with the prospect of being finalized in less than a week. See for example https://nl.hellolaw.com/node/1017.
} 


\section{The proliferation and the ban of the flash divorce option}

The accidental emergence of the new divorce option is evident in its pattern of adoptions. Flash divorce was not a part of the public discourse leading up to the same-sex marriage bill, which meant that people were initially unaware of its availability. The estimates of take-up rates of flash divorce reported in van Huis and Loozen (2009) suggest that the awareness rose throughout the year 2001, reaching full salience in the following year. In 2001, the flash option accounted for less than $2 \%$ of the divorce cases filed in the country, whereas in 2002 it accounted for more than $13 \%$. This share remained relatively stable over the next 7 years, falling somewhat towards the end of the decade.

Despite its popularity, the institution of flash divorce was controversial. As an unintended outcome of the same-sex marriage bill, flash divorce was poorly incorporated into the existing family legislation. It created legal ambiguities, and law experts grew increasingly concerned about potential problems with financial and custodial disputes of flash-divorced couples particularly of the couples who arranged their divorce without seeking any legal counsel. It also created problems for immigrant couples because the flash option was not embedded into international treaties, and couples could face problems when trying to get the flash divorce recognized in their countries of origin. For these reasons, the government passed a corrective bill which prohibited further transitions from marriage into the registered partnership, effectively banning the flash divorce option. The bill was passed on November 28, 2008, and came into effect on March 1, 2009. Over the nearly eight years of the flash divorce availability, more than 30,000 couples opted for this procedure (van Huis and Loozen 2009). This represents a sizable proportion of the total of 290,000 divorces realized within this period in the Netherlands. 


\section{International experience}

While the notion of administrative divorce may seem unusual, several countries have embedded this option into their family law systems. Denmark, Estonia and Portugal offer administrative divorces which resemble the Dutch variant: upon application, the couples filing for administrative divorce are required to present a divorce settlement contract and pay a processing fee. The divorces are processed at the municipality, and legal mediation is not required. Norwegian and Romanian variants differ from this model in two respects. Their procedures are free of charge, and they require couples with minor children to enter legal mediation prior to the divorce. Other countries offer administrative divorces executed by a notary (Latvia and Spain) or by a legal representative (Greece). Greek and Spanish variants are restricted to couples who have no minor children, whereas the Latvian variant is available for everyone. Interestingly, the Danish system is changing - as of the year 2019, the administrative divorce procedure in Denmark will require a 3-month waiting period before the divorce takes effect (Dansk Regering 2018). This period is intended to give the divorcing couples time to reflect on the terms of their divorce settlement, particularly with regard to the custodial arrangements for their children. A similar waiting period is in place in Romania.

\section{Dutch administrative data}

My empirical analysis rests on a dataset constructed from the Dutch municipal registers. The register data are maintained by Statistics Netherlands (CBS) and cover all residents living in the Netherlands between years 1995 and 2016 (the population in 2005 was 16.3 million inhabitants). Each record contains a unique personal identifier, date of birth, gender, and immigration background. I also observe full marital histories with spousal identifiers, full fertility histories with child identifiers, and residential histories over the period 1995-2016 with 
household identifiers.

The marital histories cover each resident's past and present marriages, including the marriages that were initiated and terminated prior to 1995 . This includes $3,540,794$ marriages that were on-going on 1 January 1995 and 1,859,763 marriages that began on or after this date. For each marriage, the data indicate the date of wedding, the date of divorce (i.e., the date when the divorce was recorded into the register of births, marriages and deaths) or the date of termination due to death of one of the spouses. The type of divorce procedure is not observed. Leveraging the spousal and child identifiers, I link the married individuals to their spouses and children. Residential histories are then used to determine geographic characteristics of their households.

\section{Dynamics of marriage and divorce incidence}

As an initial exercise, I investigate the aggregate flows into and out of marriage. Figure 1 shows the quarterly incidence of weddings and divorces of Dutch heterosexual couples from 1995 to 2016. The wedding incidence is adjusted for seasonality, which is necessary due to its strong seasonal component (an unadjusted plot can be found in Appendix Figure A1). The vertical dashed lines correspond to the introduction and the ban of the flash divorce option.

[Figure 1 about here]

The wedding incidence declines over time, dropping from an adjusted 23,000 weddings per quarter in the late 1990 s to 15,000 in 2016 . This decline resembles trends in other developed countries, and it is consistent with the theory of 'deinstitutionalisation' of marriage (Cherlin 2004). With respect to the two thresholds, there is little evidence that the wedding incidence was meaningfully affected by the changes of the divorce regime. There is a noticeable decrease in the 
quarterly variability after the introduction of flash divorce, however this change is unrelated to the introduction of the new divorce regime. ${ }^{6}$

The dynamics of the divorce incidence are presented in the second panel of Figure 1 and they are in a stark contrast to the wedding incidence. The number of divorces recorded at the beginning and end of the observation period is virtually the same - approximately 8500 per quarter. However, since the wedding incidence is falling, the relative incidence of divorces is increasing. In 1995, the annual divorce rate amounted to 9.1 divorces per 1000 ongoing marriages and it rose to 10.1 divorces per 1000 ongoing marriages in $2016 .{ }^{7}$ The graph also reveals that the risks of divorce were elevated throughout the period of flash divorce availability. The divorce incidence increases around the introduction of the policy and falls after its ban.

The 2001 increase of divorce incidence is, however, unlikely to be attributable to the new divorce option. The graph shows that the divorce incidence started growing prior to the introduction date (April 1, 2001), and the two quarters adjacent to the threshold show no sign of discontinuity. The absence of a discontinuous change conforms with the institutional background presented above - the new divorce regime was not immediately salient to divorcing couples, and few exercised the flash option within the first year of its availability. The cause of the rising incidence of divorce between the years 2000 and 2001 lies elsewhere, and to the best of my knowledge it remains unaddressed by the academic literature. One hypothesis is that the increase is a consequence of the slowing economy (De Groot 2002), while other hypotheses link it to the

\footnotetext{
${ }^{6}$ As documented by Kabátek and Ribar (2018), the observed fluctuations of quarterly wedding incidence are attributable to couples who are targeting easily memorable wedding dates, such as 08/08/08 or 05/06/07. In the second half of each decade, these dates fall predominantly on spring and summer months, and their popularity is so large that it enhances the overall seasonality of weddings.

${ }^{7}$ The notion of divorce rate used throughout this paper is not equivalent to the crude divorce rate which is often found in national statistics (England and Kunz 1975). The crude divorce rate is defined relative to the population, whereas the divorce rate used here is defined relative to the pool of couples at risk of divorce.
} 
same-sex marriage legislation. ${ }^{8}$

Compared to the introduction, the ban of the flash divorce option in March 2009 marks a clear discontinuity of the divorce trend. The incidence of divorce dropped from 8,700 per quarter to 7,400 , suggesting that the availability of flash divorce did indeed have a sizable effect on marital stability. The immediate drop in the first quarter following the ban is more pronounced than in the following quarters. This is likely a mechanical consequence of the ban: The couples who decided to split shortly after March 12009 were no longer able to exercise the fast administrative divorce option. Instead, they had to wait several months for their conventional divorce to get processed. This processing lag would lead to a temporary dip of the divorce incidence which would be compensated as soon as the first wave of post-reform divorces got processed. $^{9}$

\section{Econometric Analysis}

The following econometric analysis is aimed at estimating the effect of flash divorce availability on marital stability. The identification is aided by the ban of the flash divorce option. The introduction of the flash divorce option is not considered because the corresponding discontinuity of divorce incidence is not sharp (due to the low levels of initial awareness), and because the underlying trends may be distorted by simultaneous policy changes.

\footnotetext{
${ }^{8}$ Trandafir (2015) considers the argument that the same-sex marriage bill may have destabilized the institution of marriage in the Netherlands. This argument was purportedly used in parliamentary debates preceding the implementation of the same-sex bill. The claim is that the reform could induce heterosexual couples to divorce (or not to marry in the first place) either as a form of protest against the same-sex legislation, or as a result of spousal conflict stemming from disagreement over the controversial policy. Trandafir shows no evidence of a drop in heterosexual wedding incidence. His analysis however does not consider the divorce channel, leaving the argument as a possible explanation of the 2001 increase of divorce incidence.

${ }^{9}$ The dip could be also potentially attributed to the strategic behavior of couples who had expedited their divorce process in order to qualify for the flash divorce option. However, the administrative data show little evidence of prereform bunching, and I conduct robustness checks to make sure that the results are not driven by this confounding variation.
} 
The principal estimation strategy employs a regression discontinuity (RD) design. The RD model evaluates the incidence of divorces in a restricted sample of marriages observed within the 3-year window around the ban of the flash divorce option. This restriction renders the sample of marriages relatively homogenous, and allows me to abstract from modelling the compositional changes within the pool of married couples. Characteristics of the 3,757,400 married couples observed within the 3-year window are summarized in Table 2.

\section{[Table 2 about here]}

The unit of observation is the marital outcome (continuation or divorce) for a given marriage within a given period of time. The period is defined as a three-month interval (narrower interval definitions have been employed as well, leading to very similar results). Compared to standard calendar quarters, the three-month intervals used in this paper are shifted one month backwards, so that the date of the reform (March 1, 2009) coincides with the first day of the first post-reform interval. Note that I still call this shifted three-month interval a 'quarter' and use this nomenclature throughout the paper.

The RD model uses a donut hole specification, excluding the first quarter which follows the ban (because the divorce incidence was distorted by the post-reform processing delay). The policy effect is identified through the discrete change of divorce propensities at the threshold. The functional form of the RD model is logit, with the probability of divorce $y$ defined as $\operatorname{Pr}\left[y_{i t}=1 \mid \mathbf{x}_{i t}, \boldsymbol{\beta}\right]=\frac{1}{1+\exp \left(-\mathbf{x}_{i t} \boldsymbol{\beta}\right)}$

The couples are indexed by $i$ and time is indexed by $t$. The exponentiated term corresponds to the product of a vector of covariates $\mathbf{x}$, and a parameter vector $\boldsymbol{\beta}$ which is defined as follows, 
$\mathbf{x}_{i t} \boldsymbol{\beta}=\beta_{0}+\beta_{1} \cdot$ Flash $_{t}+f\left(t, \boldsymbol{\beta}_{2}\right)+\boldsymbol{\beta}_{3} \cdot \mathbf{q}_{t}$.

The covariates include a dummy indicating the availability of flash divorce (Flash), a flexible time trend polynomial $f\left(t, \boldsymbol{\beta}_{2}\right)$, and a vector of quarterly dummies (q) capturing seasonality. The baseline specification of the time trend is using linear spline function with a knot at the point of the ban $c$,

$f\left(t, \boldsymbol{\beta}_{2}\right)=\beta_{21}(t-c)+$ Flash $_{t} \cdot \beta_{2}(t-c)$.

In order to ensure robustness of the results, other time trend specifications are considered as well. The error terms $\varepsilon$ are assumed to be drawn from the type 1 generalized extreme value distribution.

The identification of the RD model is aided by variation of the outcome variable over time. This makes the model susceptible to confounding effects of other time-varying processes which may be affecting the stability of marriages (such as macroeconomic conditions). To account for these confounders, I complement the RD model with a regression discontinuity difference-in-differences (RD-DD) model. The RD-DD model operates with a control group of couples whose outcomes were not affected by the flash divorce legislation. In this analysis, the control group consists of cohabiting (de facto) couples. Cohabiting couples can be considered a valid control group, because while they were subject to the same macroeconomic and societal processes as married couples, the flash divorce legislation did not affect the rules governing dissolution of their unions. De facto unions can be dissolved without any legal or administrative process, which means that the availability of flash divorce option was not relevant for cohabiting couples.

The policy effect is identified through the difference between the RD effects 
corresponding to the treatment and the control group. The functional form of the principal RDDD model is an interacted version of the RD model,

$\mathbf{x}_{i t} \boldsymbol{\beta}=\beta_{0}+\beta_{1} \cdot$ Flash $_{t}+f\left(t, \boldsymbol{\beta}_{2}\right)+\boldsymbol{\beta}_{3} \cdot \mathbf{q}_{t}+$ Married $\cdot\left(\gamma_{0}+\gamma_{1} \cdot\right.$ Flash $\left._{t}+f\left(t, \boldsymbol{\gamma}_{2}\right)+\boldsymbol{\gamma}_{3} \cdot \mathbf{q}_{t}\right)$,

in which the main coefficient of interest is $\gamma_{1}$. I also estimate an alternative specification of the RD-DD model which uses time fixed effects $\lambda_{t}$,

$\mathbf{x}_{i t} \boldsymbol{\beta}=\beta_{0}+$ Married $\cdot\left(\gamma_{0}+\gamma_{1} \cdot\right.$ Flash $\left._{t}\right)+\lambda_{t}$.

One disadvantage of using cohabiting couples as the control group is that I cannot identify cohabiters who are childless (the structure of the data renders them observationally equivalent to two unrelated individuals who share the same household). The RD-DD model is therefore restricted to married and cohabiting couples with children, and serves primarily as a validation exercise for the RD model estimates.

\section{Baseline results}

The results are presented both graphically and numerically. Graphical representation of the RD estimate is shown in Figure 2, which plots the realized and predicted divorce rates around the ban of the flash divorce option.

[Figure 2 about here]

The graph shows a clear drop of divorce rate at the point of discontinuity. Estimates of the corresponding RD effect are listed in the first column of Table 3. In relative terms, the period of flash divorce availability was associated with $11.6 \%$ higher risks of divorce than the period following the ban. In absolute terms, this translates into 1 additional divorce per 1,000 married couples per year, totaling approximately 3,800 divorces per year. The estimates are statistically 
significant and robust across multiple specifications which are listed in Table A1.

[Table 3 about here]

The RD model is accompanied with the RD-DD model for couples with children. The control group of cohabiting couples is extracted from population registers using couples' residential histories and parent-child identifiers. This means that each couple in the control group shares at least one biological child, and was recorded as cohabiting in the beginning of the observation window. In order to make the treatment and control group more comparable, the same restriction is imposed on the married couples as well. Since the cohabiting couples are not required to formally register their separations, I define a separation of a cohabiting couple as the point when one of the spouses moves out of the shared residence. This event is treated as a separation only if the couple is not observed to move back together within a period of two years. The two-year condition is put in place to account for other reasons for residential separations, such as seasonal work engagements, studies abroad, or a sequential move into a new residence. Figure 3 shows a graphical representation of the RD-DD results, plotting the realized divorce and separation rates against the fitted lines for both married and cohabiting couples with children.

[Figure 3 about here]

The plots show that while married couples experience a discrete drop of the divorce rate at the point of discontinuity, de facto couples are not subject to a similar change. Corroborating the visual evidence, the RD-DD estimate listed in Table 3 is only marginally smaller than the RD estimate for married couples with children. This bolsters the claim that the measured change of divorce rate should be causally attributed to the availability of flash divorce and not to other 
time-varying processes. In terms of the magnitude, the estimates of relative effects for couples with children are similar to those corresponding to the full sample of married couples. The absolute effects are however smaller, because the divorce incidence is lower among couples with children. In nominal terms, the $10.8 \%$ increase of the divorce rate corresponds to 2,300 divorces of families with children per year. The estimates are statistically significant and robust across multiple specifications which are listed in Table A2.

The similarity of the RD-DD effect for couples with children and the effect found in the full sample may seem counterintuitive - one might expect couples with children to be less responsive to the flash divorce availability, because their settlements were complicated by custodial arrangements and child support plans. However, these complications were counterweighed by substantially larger reductions of divorce costs for families with children (recall that the couples with children are required to attend court hearings, which raises the costs of conventional divorce by court hearing fees and additional lawyer fees). The idiosyncratic design of the policy (and of the legal system in which it was embedded) therefore made the couples with children as responsive to the flash divorce legislation as the couples who were childless.

\section{Heterogeneity of the baseline results}

While certain features of the flash divorce option led to homogenous responses across distinct population groups, other features had the opposite effect. I explore this heterogeneity by estimating the principal specification of the RD model for specific sub-samples of married couples. I choose the subsamples to highlight the practical considerations which either encouraged couples to take up the flash divorce option, or deterred them from doing so. The results of these analyses are listed in Table 4. 
[Table 4 about here]

First, I consider the role of relative earning potential, isolating couples whose wages were close to each other, and couples whose wages were far apart. The intuition is that couples with similar earning potentials should respond more to the flash legislation, because they face fewer obstacles to informal divorce settlement. With similar levels of spousal earnings, the settlements are unlikely to be complicated by bargaining over alimony, pensions, and overall maintenance of living standards. These issues will be more salient to the single-earner couples and couples with very dissimilar earnings, who are expected to rely more often on the advice of lawyers, and therefore respond less to the flash divorce legislation.

In order to approximate spousal earning potential, I use hourly wages observed over the year 2007. I do not use annual earnings, because many married women in the Netherlands work part-time, and their hourly wages are therefore more indicative of their earning potential. The pool of married couples is split into three groups, distinguishing couples whose hourly wages were 1) less than 5 Euros apart, 2) between 5 to 10 Euros apart, and 3) At least 10 Euros apart. The last group also contains single-earner households. The results are presented in the first three rows of Table 4. In line with the intuition, the couples with similar hourly wages are shown to be significantly more responsive to the flash divorce legislation than couples with dissimilar hourly wages. The divorce risks of the most homogenous group were $15.5 \%$ higher under the flash divorce regime, compared to $9.3 \%$ higher among couples in the least homogenous group.

Second, I consider the role of household income. Couples who are expected to be most responsive to the legislation are middle-income couples, because low-income couples are sheltered from a large fraction of the legal costs, and high-income couples are likely to be less sensitive to the costs of divorce. I split the couples into terciles according to their joint annual 
income in the year 2007, roughly separating the low-income, middle-income, and high-income couples. The corresponding RD estimates are presented in the second block of Table 4. Also in this case, the empirical estimates are in accord with the expectations. The low-income couples are shown to be largely unaffected by the ban of flash divorce, facing $4 \%$ higher divorce risks under the flash divorce regime. In contrast, the risks faced by middle-income couples were $15 \%$ higher, and the risks faced by high-income couples were $10 \%$ higher. The estimates for middleincome and high-income couples are statistically significant.

Third, I investigate the heterogeneity with respect to the spousal immigration background, distinguishing between native Dutch couples, immigrant couples, and blended couples in which one spouse is an immigrant and the other is a native. Heterogeneous effects among these groups are also expected, because immigrant couples were more affected by the problems with recognition of flash divorces outside of the Netherlands. Accordingly, the couples with (partial) immigrant background are expected to respond less to the flash divorce legislation than the natives. This is confirmed by the RD estimates which show that the effect among native couples is $12 \%$, whereas the effect among immigrant couples is $9 \%$. The difference between these two effects is statistically significant. The relative effect for blended couples lies in between the two, however note that the absolute effect for blended couples is much larger. This is caused by substantially higher divorce risks faced by couples with dissimilar immigration background.

Lastly, I investigate the role of distance to courts. The couples living in areas which are poorly connected to the court network are expected to be more responsive to the legislation, because the flash divorce option allowed them to administer their divorce locally. For this exercise, I proxy the distance to courts by municipal urbanization levels. I prefer the urbanization levels 
over Euclidean distance to courts, because local urbanization better captures the degree of connectedness to the regional centers. The urbanization level is captured by an ordered scale ranging from 1 for the least urbanized regions of the Netherlands to 5 for the densest cities. A map of municipal urbanization levels and locations of regional courts is presented in Figure 4.

[Figure 4 about here]

If the time and monetary costs of commuting play a considerable role in divorce decisions, we should see stronger effects among couples living in the least urbanized areas of the Netherlands. The results presented in the fourth block of Table 4 confirm this reasoning. The couples living in more urbanized areas (with urbanization index ranging from 3 to 5) were subject to $10 \%$ higher risks of divorce before the ban of flash divorce. In contrast, couples living in the areas with below-average urbanization were subject to significantly stronger effects. The effects were strongest among couples living in the least urbanized areas (with the urbanization index equal to one) who were subject to a $21 \%$ increase in the risks of divorce under the flash divorce regime. The effect, however, is estimated with low precision due to the smaller sample size and lower incidence of divorces in the least urbanized regions.

\section{Robustness checks}

The estimates of the flash divorce effect have been subjected to a battery of robustness checks to ensure their stability. The results corresponding to these checks are listed in Table A.1 First, I experiment with the specification of the time trend, replacing the linear spline consecutively by a simple linear trend, quadratic trend, and a quadratic spline. All three specifications yield significant effects, with the effects corresponding to the linear and quadratic specification being nearly identical to the baseline effect. The effect captured by the quadratic 
spline specification is considerably larger than the baseline, which is likely due to overfitting.

Next, I change the sample selection by: expanding the window of observation to 18 quarters surrounding the ban; dropping couples who got married prior to the introduction of the UD legislation; and expanding the donut hole to also exclude the last quarter preceding the ban. The last robustness check is conducted to account for potential surge of last-minute divorces preceding the ban. The reform bill was passed in late November 2008, which could indeed render the excluded quarter susceptible to such anticipatory behavior. ${ }^{10}$ Nevertheless, all three specifications yield estimates of the effect which are not statistically different from the baseline. Further robustness checks involve changing the model specification from logit to linear probability model, and including current marriage duration among the covariates. Their results are also in line with the baseline.

I also subject the RD-DD model to robustness checks including changing the trend specification, and replacing the time trend by time fixed effects. The results of these robustness checks also support the effect size found in the baseline specification of the model.

\section{External validity of the estimated effects}

The empirical analysis presented above reveals that the availability of administrative divorce in the Netherlands led to a sizable reduction in marital stability. Considering the similarity of the Dutch flash divorce option to other variants of administrative divorce which are currently in place in other European countries, it can be expected that the marital stability in these countries is influenced by the administrative divorce option as well.

These country-specific effects on marriage stability may be however stronger or weaker,

\footnotetext{
${ }^{10}$ While such behavior is possible, an analysis of Google Trends reveals no spike of flash divorce searches in the period leading up to the ban. Nor could I retrieve any news articles which would report on the passing of the corrective bill and its consequences. It appears that the ban of the flash divorce option was indeed an unexpected policy shock accompanied by minimal anticipatory behavior.
} 
depending on certain features of the institutional design. On the one hand, the effects measured in the Netherlands were pulled down by the problems with the legal status of flash divorcees and their international recognition. The effects of other variants of the administrative divorce option could be therefore stronger, provided that the procedures are well-embedded into the national and international law systems. On the other hand, some countries use administrative divorce procedures which are stricter than the Dutch variant, requiring couples to engage in legal mediation, or imposing waiting periods. In such cases, the effects of administrative divorce are likely to be moderated by the extra costs embedded in the stricter design of the policy. However even then, the divorce effect is unlikely to disappear completely since the total costs of the mediated administrative procedure are still likely to be lower than the costs of conventional divorce.

\section{Conclusion}

In this paper, I show that the costs of divorce are an important factor influencing marital stability. I do so by analyzing a unique policy shock which temporarily reduced the costs of divorce for married couples in the Netherlands. This policy shock consisted of the introduction and the later ban of the 'flash divorce', an administrative divorce option which allowed couples to get divorced in a streamlined procedure at the local municipality. The flash-divorcing couples were not required to seek legal mediation and they did not have to file for a divorce through the court system. This made the optional procedure substantially cheaper and faster than the conventional divorce.

My empirical analysis rests on an administrative dataset covering the full population of married couples in the Netherlands. Leveraging the discontinuous change of the divorce rate around the ban of the flash divorce option in April 2009, I show that the Dutch couples were 
subject to risks of divorce that were $11.6 \%$ higher under the flash divorce regime. This increase of the divorce risks translates into approximately one additional divorce per 1,000 couples per year, totaling 3,800 divorces per year. This baseline result is derived using a RD model and is robust to various changes to the model specification and sample selection criteria. It is also confirmed by a RD-DD model using cohabiting couples with children as a control group who were unaffected by the reform.

The subsample analysis reveals that the estimated effect exhibits considerable heterogeneity with respect to certain characteristics of the married couples. First, the effect is stronger among couples in which both the husband and the wife have similar earning potentials. The similarity of earning potentials facilitates informal settlement of alimony and pension arrangements, and renders the couples more responsive to the flash divorce option. Second, the effect is stronger among middle-income couples, for whom the costs of conventional divorce were particularly high. Third, the effect is weaker among immigrant couples. This is likely due to the problems with the recognition of flash divorces outside of the Netherlands. Fourth, the effect is stronger among couples living in the least urbanized regions of the country. The couples living in these areas were more responsive to the administrative divorce option, because the possibility of divorce at the local municipality saved them the costs of commuting to the regional centers.

The lower stability of marriages under the Dutch flash divorce regime is of considerable policy interest, especially for the countries whose legal systems allow married couples to exercise the administrative divorce option. The divorce rates in these countries are often higher than those observed among their neighbours (Denmark being a particularly poignant case), and the administrative option may well be contributing to the observed disparities. An obvious policy aimed at increasing the marital stability would therefore be to follow the Dutch example and ban 
the administrative procedure (or increase its costs). However, while marital stability is likely to benefit from such policy, its normative merit is yet to be determined. Ex ante, it is unclear which policy regime is associated with greater social welfare and a careful analysis of the outcomes of families divorcing under the two policy regimes is necessary to resolve this question. From this perspective, the Dutch policy shock offers great potential for follow-up analyses to yield novel and highly relevant insights into the causal effects of the administrative divorce option. 


\section{References}

Aygün, Murat. 2015. "Het Wetvoorstel Wet Scheiden Zonder Rechter." Tilburg University. Boele-Woelki, Katharina, Olga Cherednychenko, and Lieke Coenraad. 2003. "Grounds for

Divorce and Maintenance Between Former Spouses. The Netherlands." in European Family

Law in Action - Volume I, Grounds for Divorce. Intersentia.

Brassiolo, Pablo. January 19, 2016. "Domestic Violence and Divorce Law: When Divorce

Threats Become Credible.” Journal of Labor Economics 34(2):443-77.

CBS. 2010. "StatLine: Gebieden in Nederland."

Cherlin, Andrew J. 2004. "The Deinstitutionalization of American Marriage." Journal of

Marriage and Family 66(4):848-61.

Chiappori, Pierre-Andre, Murat Iyigun, Jeanne Lafortune, and Yoram Weiss. April 25, 2016.

"Changing the Rules Midway: The Impact of Granting Alimony Rights on Existing and

Newly Formed Partnerships.” The Economic Journal 127(604):1874-1905.

Chiappori, Pierre-Andre, Murat Iyigun, and Yoram Weiss. 2015. "The Becker-Coase Theorem

Reconsidered." Journal of Demographic Economics 81(2):157-77.

Dansk Regering. 2018. Aftale Om Ét Samlet Familieretligt System.

England, J. Lynn and Phillip R. Kunz. 1975. "The Application of Age-Specific Rates to

Divorce." Journal of Marriage and Family 37(1):40-46.

Felkey, Amanda J. 2011. "Will You Covenant Marry Me? A Preliminary Look at a New Type of Marriage.” Eastern Economic Journal 37(3):367-89.

Friedberg, Leora. 1998. "Did Unilateral Divorce Raise Divorce Rates? Evidence from Panel

Data." The American Economic Review 88(3):608-27.

González, Libertad and Tarja Viitanen. June 23, 2017. "The Long-Term Effects of Legalizing

Divorce on Children." Oxford Bulletin of Economics and Statistics 80(2):327-57.

González, Libertad and Tarja K. Viitanen. 2009. "The Effect of Divorce Laws on Divorce Rates in Europe." European Economic Review 53(2):127-38.

De Groot, Natasja. 2002. "Scheiden Is Lijden, Zelfs Bij Flitsscheiding.” Volkskrant, April 10, accessed July 16, 2018.

Gruber, Jonathan. 2004. "Is Making Divorce Easier Bad for Children? The Long\&\#x2010;Run Implications of Unilateral Divorce.” Journal of Labor Economics 22(4):799-833.

van Huis, Mila and Suzanne Loozen. 2009. Dertigduizend Flitsscheidingen, 2001-2009.

Kabátek, Jan and David C. Ribar. January 2018. "Not Your Lucky Day: Romantically and Numerically Special Wedding Date Divorce Risks.” Journal of Population Economics.

Matouschek, Niko and Imran Rasul. 2008. "The Economics of the Marriage Contract: Theories and Evidence." The Journal of Law and Economics 51(1):59-110.

Peters, H. Elizabeth. 1986. "Marriage and Divorce: Informational Constraints and Private Contracting." The American Economic Review 76(3):437-54.

Rechtspraak. 2018. "Rechtbanken."

Stevenson, Betsey and Justin Wolfers. February 1, 2006. "Bargaining in the Shadow of the Law: Divorce Laws and Family Distress*." The Quarterly Journal of Economics 121(1):267-88.

Trandafir, Mircea. 2015. "Legal Recognition of Same-Sex Couples and Family Formation." Demography 52(1):113-51.

Waaldijk, Kees. 2004. "Major Legal Consequences of Marriage, Cohabitation and Registered Partnership for Different-Sex and Same-Sex Partners in the Netherlands." Pp. 137-153 in More or less together: Levels of legal consequences of marriage, cohabitation and 
registered partnerships for different-sex and same-sex partners. A comparative study of nine European countries. Paris, France: Institut National d'Études Démographiques.

Wolfers, Justin. 2006. "Did Unilateral Divorce Laws Raise Divorce Rates? A Reconciliation and New Results.” American Economic Review 96(5):1802-20. 


\section{Table 1: An illustration of the costs involved in the conventional and flash divorce procedures}

\begin{tabular}{lcc} 
& Conventional divorce & Flash divorce \\
\hline Municipal fees & $€ 100$ & $€ 200^{1}$ \\
Court fees & $€ 200$ & - \\
Lawyer fees & $€ 2400^{2,3}$ & $€ 300^{3}$ \\
Notary fees & $€ 600^{3}$ & $€ \mathbf{3 3 0 0}$ \\
\hline Total fees & & \\
\hline Notes: & & \\
${ }^{1}$ Municipal fees are higher for the flash divorce option, because the couple needs to make two \\
administrative changes: a transition into the partnership, and then a termination of the \\
partnership. \\
${ }^{2}$ Lawyer fees are not applicable to spouses with low levels of income. The low-income couples \\
are entitled to subsidized legal services provided by the city council. \\
${ }^{3}$ Indicative averages reported by the Dutch divorce law websites.
\end{tabular}


Table 2: Summary statistics, married couples observed between years 2007 and 2010

\begin{tabular}{lcc} 
Variable & Mean & St. Dev. \\
\hline Year of marriage & 1983.94 & 16.64 \\
Duration of marriage (in years) & 22.53 & 16.63 \\
Age, husband & 51.64 & 14.81 \\
Age, wife & 48.94 & 14.83 \\
First-time married & $88.13 \%$ & \\
Immigration background & & \\
Native couples & $83.36 \%$ & \\
Blended couples & $7.59 \%$ & \\
Immigrant couples & $9.05 \%$ & \\
Education level, husband & & \\
Primary education & $3.06 \%$ & \\
Secondary education & $17.70 \%$ & \\
Tertiary education & $11.05 \%$ & \\
Missing records & $68.19 \%$ & \\
Education level, wife & & \\
Primary education & $5.30 \%$ & \\
Secondary education & $20.48 \%$ & \\
Tertiary education & $11.69 \%$ & \\
Missing records & $62.53 \%$ & \\
Number of children & & \\
Childless & $21.66 \%$ & \\
1 & $14.48 \%$ & \\
2 & $39.70 \%$ & \\
3 & $16.65 \%$ & \\
5 & $4.80 \%$ & \\
Labor supply (spouses aged 64 and less) & $2.71 \%$ & \\
Employed, husband & & \\
Employed, wife & $83.16 \%$ & \\
Hourly wage, in $€$, husband & $62.98 \%$ & \\
Hourly wage, in $€$, wife & 16.67 & 97.48 \\
Annual household income, in $€ 1000$ & 10.72 & 68.47 \\
Urbanization index (1=min , 5=max) & 40.05 & 54.51 \\
\hline & 2.96 & \\
\hline & & \\
& & \\
& &
\end{tabular}

Number of marriages observed

$3,757,400$

Note: Characteristics of the population of married couples observed within the 12-quarter interval surrounding the ban of the flash divorce option. The availability of education records is increasing over time, reaching full coverage for the cohort born in 1987. Labor supply characteristics are restricted to spouses below the retirement age (65). The wage statistics are conditional on employment, and annual income excludes rents and government transfers. 
Table 3: Estimates of the effect of flash divorce availability on quarterly divorce rate

\begin{tabular}{l} 
Model Specification \\
\cline { 2 - 4 } $\begin{array}{l}\text { Coefficient } \\
\text { (\% change })\end{array} \begin{array}{c}\text { Standard } \\
\text { error }\end{array}$
\end{tabular}


Table 4: RD subsample estimates

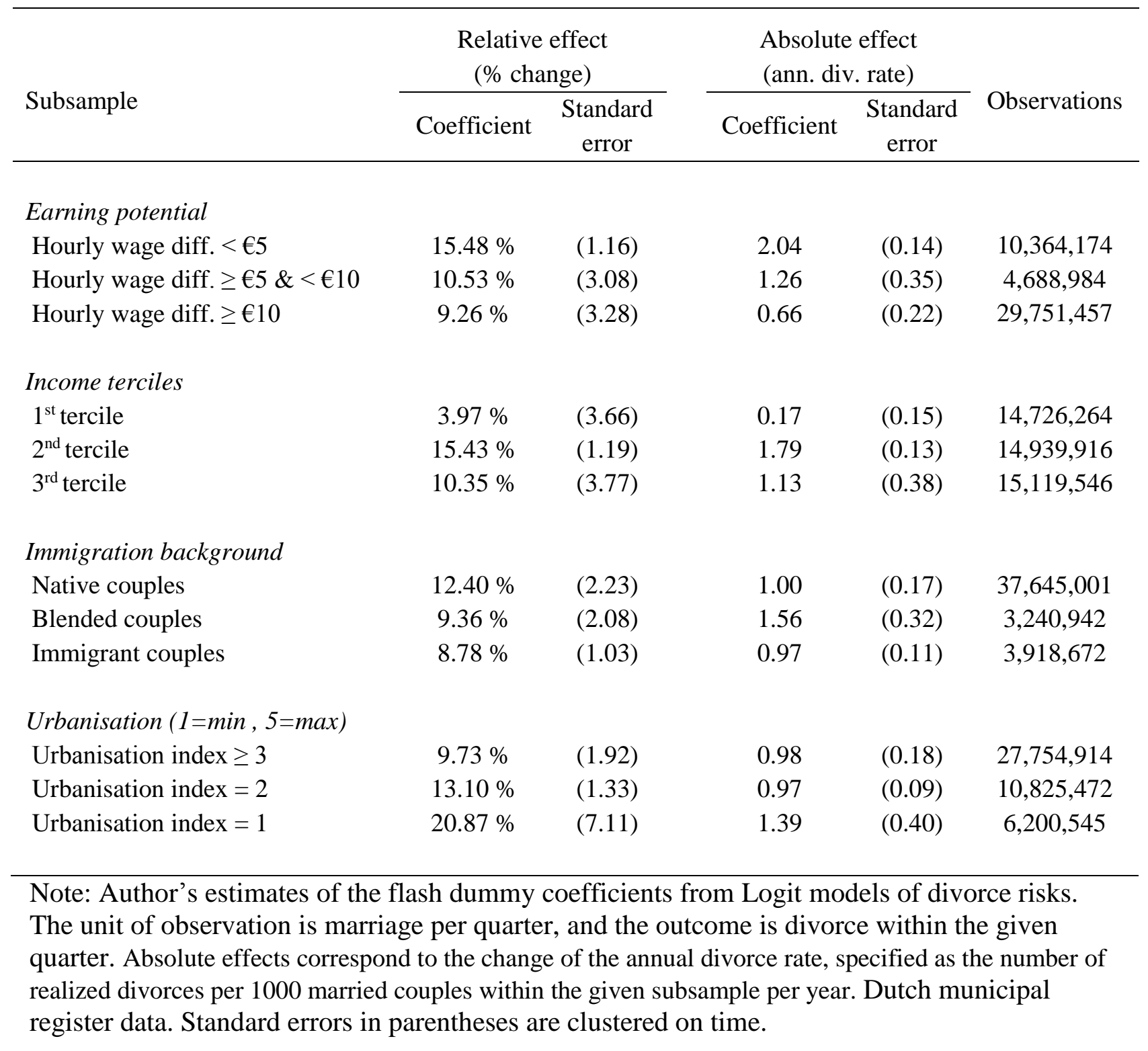


Figure 1: Wedding and divorce incidence

(a) Quarterly wedding incidence, seasonally adjusted, 1995-2016

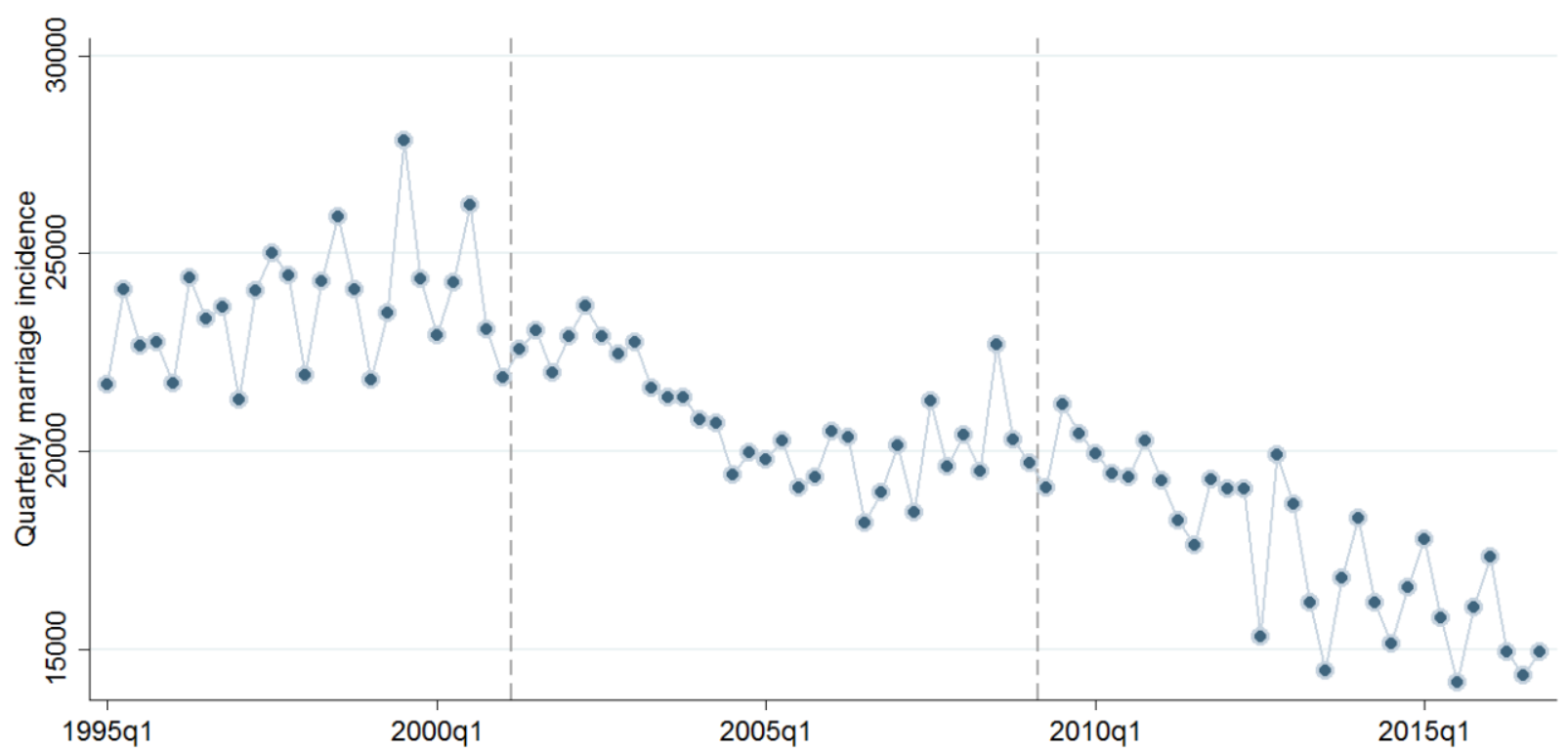

(b) Quarterly divorce incidence, 1995-2016

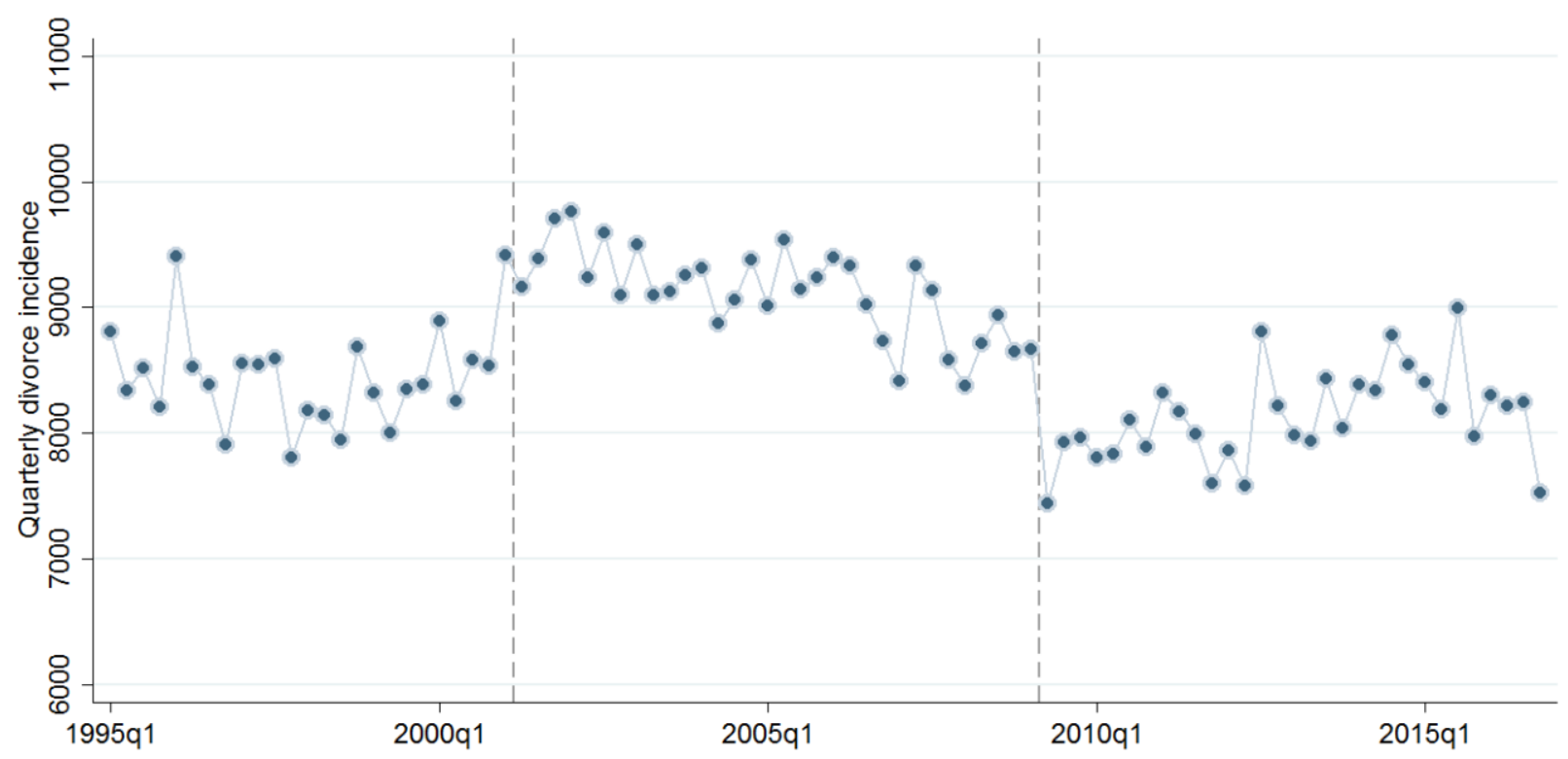

Note: Author's calculations of quarterly wedding and divorce incidence in the Netherlands between years 1995 and 2016. Vertical dashed lines represent the introduction and the ban of the flash divorce option. 
Figure 2: Discontinuity of the quarterly divorce rate around the ban of the flash divorce option

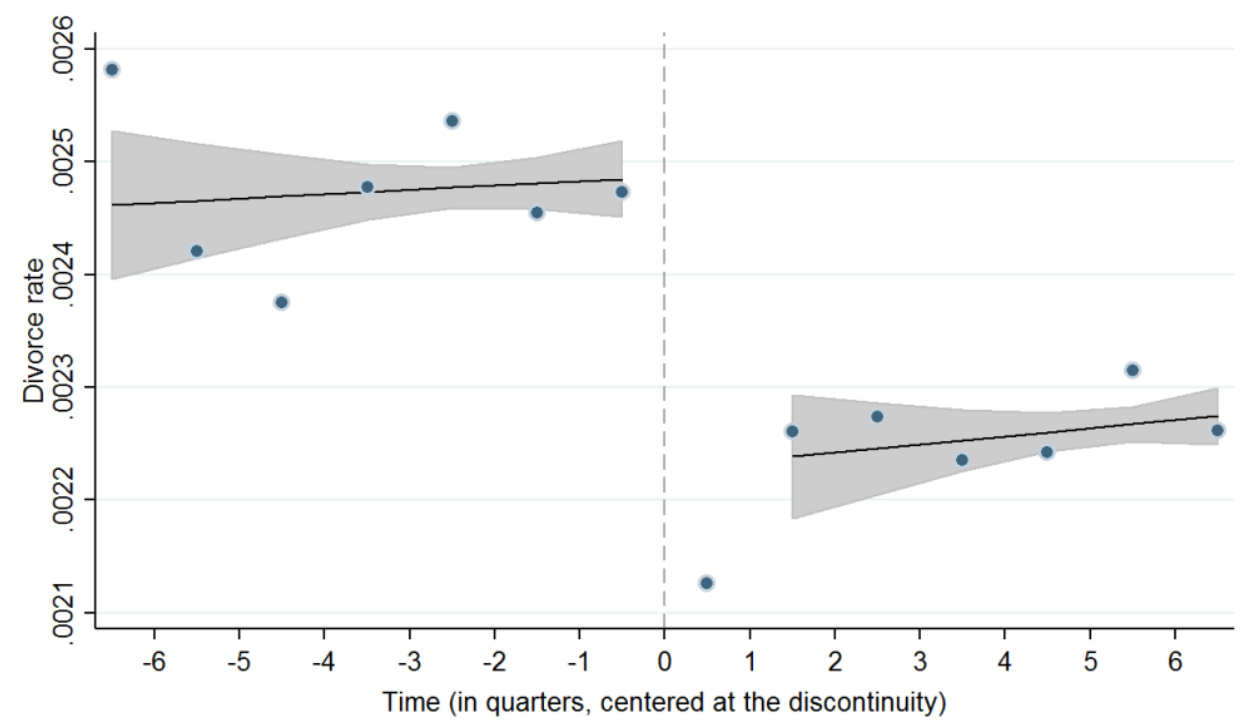

Note: Author's calculations of realized and predicted quarterly divorce rates around the ban of the flash divorce option. The divorce rate is defined as the number of divorces realized over the given quarter relative to the stock of marriages. The time is equal to zero on the date of the ban. Fitted lines correspond to the baseline logit model with a linear spline at the point of the discontinuity. 
Figure 3: Dynamics of the divorce rate and separation rate around the ban of the flash divorce option

(a) Married couples with children

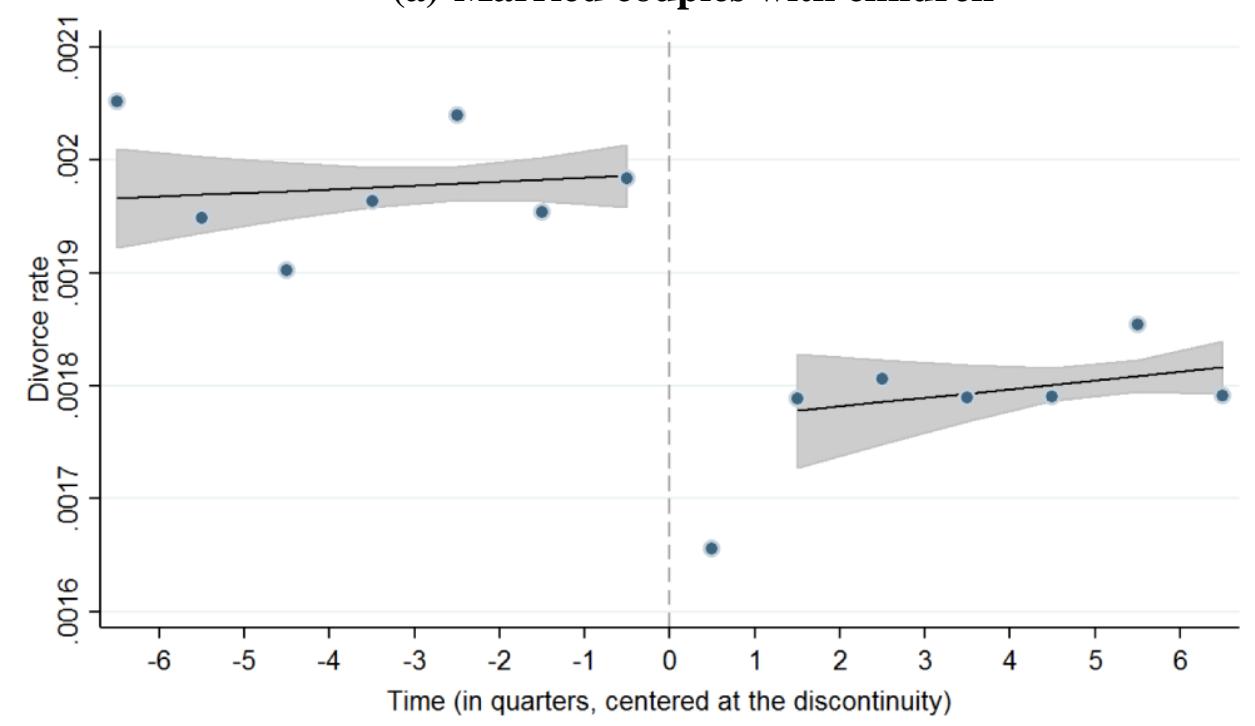

(b) Cohabiting couples with children

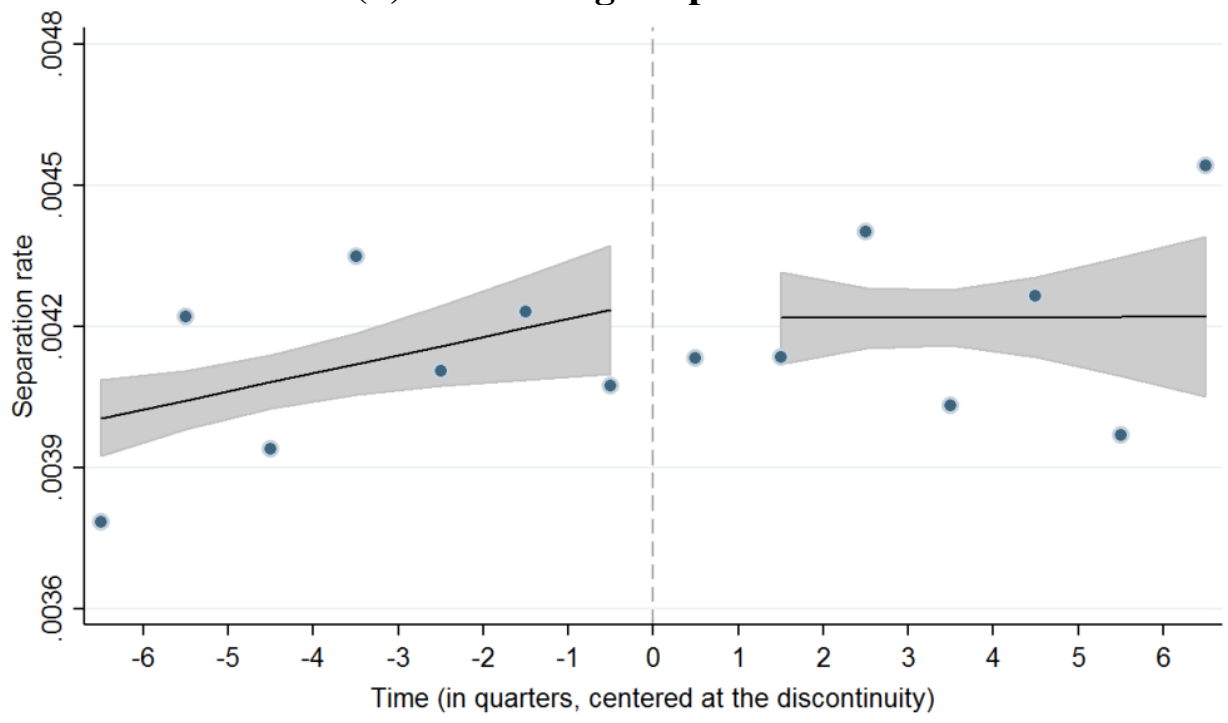

Note: Author's calculation of realized and predicted quarterly divorce and separation rates around the ban of the flash divorce option. Separations are defined as residential separations that have not been followed by repartnering of the same couple in less than 2 years. Fitted lines correspond to the RD-DD logit model with a linear spline at the point of the discontinuity. 
Figure 4: Municipal urbanization levels and location of regional courts in the Netherlands

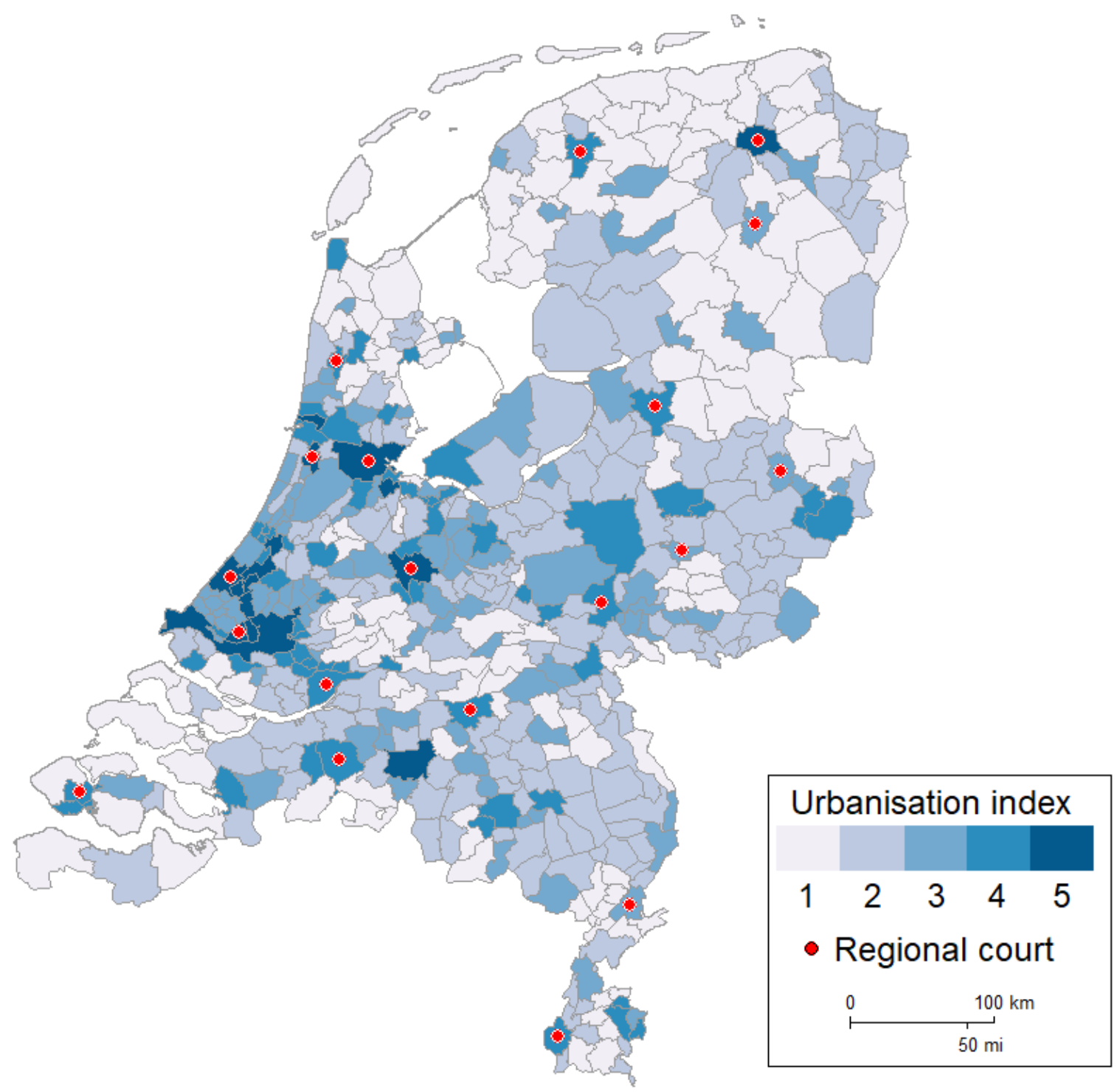

Note: The urbanisation data is sourced from CBS (2010), and the court locations are sourced from Rechtspraak (2018). The urbanisation index is constructed by CBS from the average density of residential and business addresses registered at the given municipality. 


\section{Supplementary Appendix - for online publication only}

Table A1: RD estimates of the effect of flash divorce availability on quarterly divorce rate

\begin{tabular}{|c|c|c|c|c|c|c|c|}
\hline Variable & Linear spline & Linear trend & $\begin{array}{l}\text { Quadratic } \\
\text { trend }\end{array}$ & $\begin{array}{l}\text { Quadratic } \\
\text { spline }\end{array}$ & $\begin{array}{l}\text { Lin. spline, } \\
\text { duration FE }\end{array}$ & $\begin{array}{l}\text { Lin. spline, } \\
\text { two Q donut }\end{array}$ & $\begin{array}{l}\text { Lin. spline, } \\
\text { 18Q window }\end{array}$ \\
\hline Flash & $\begin{array}{l}11.573 * * * \\
(1.913)\end{array}$ & $\begin{array}{l}11.469 * * * \\
(1.878)\end{array}$ & $\begin{array}{l}11.682 * * * \\
(1.928)\end{array}$ & $\begin{array}{l}18.009 * * * \\
(2.779)\end{array}$ & $\begin{array}{l}11.701 * * * \\
(1.933)\end{array}$ & $\begin{array}{l}9.852 * * * \\
(2.037)\end{array}$ & $\begin{array}{l}11.128 * * * \\
(2.184)\end{array}$ \\
\hline Time (before ban) & $\begin{array}{c}0.311 \\
(0.312)\end{array}$ & & & $\begin{array}{c}1.772 \\
(1.335)\end{array}$ & $\begin{array}{c}0.546^{*} \\
(0.317)\end{array}$ & $\begin{array}{c}0.279 \\
(0.313)\end{array}$ & $\begin{array}{l}-0.143 \\
(0.145)\end{array}$ \\
\hline Time (after ban) & $\begin{array}{c}0.171 \\
(0.310)\end{array}$ & & & $\begin{array}{l}2.608 * * * \\
(0.697)\end{array}$ & $\begin{array}{c}0.464 \\
(0.311)\end{array}$ & $\begin{array}{l}-0.104 \\
(0.305)\end{array}$ & $\begin{array}{l}-0.304 \\
(0.235)\end{array}$ \\
\hline Second quarter & $\begin{array}{c}1.474 \\
(1.051)\end{array}$ & $\begin{array}{c}1.547 \\
(0.956)\end{array}$ & $\begin{array}{c}1.474 \\
(1.037)\end{array}$ & $\begin{array}{l}2.271 * * \\
(1.167)\end{array}$ & $\begin{array}{c}1.447 \\
(1.054)\end{array}$ & $\begin{array}{c}2.306 * \\
(1.248)\end{array}$ & $\begin{array}{l}-1.793 \\
(1.168)\end{array}$ \\
\hline Third quarter & $\begin{array}{l}4.451 * * * \\
(1.209)\end{array}$ & $\begin{array}{l}4.511 * * * \\
(1.175)\end{array}$ & $\begin{array}{l}4.385^{* * *} \\
(1.182)\end{array}$ & $\begin{array}{l}4.882 * * * \\
(0.657)\end{array}$ & $\begin{array}{l}4.289 * * * \\
(1.212)\end{array}$ & $\begin{array}{l}5.140 * * * \\
(1.344)\end{array}$ & $\begin{array}{l}-2.279 \\
(1.443)\end{array}$ \\
\hline Fourth quarter & $\begin{array}{c}1.140 \\
(1.145)\end{array}$ & $\begin{array}{c}1.213 \\
(1.021)\end{array}$ & $\begin{array}{c}1.075 \\
(1.168)\end{array}$ & $\begin{array}{l}1.716^{* *} \\
(0.852)\end{array}$ & $\begin{array}{c}1.087 \\
(1.149)\end{array}$ & $\begin{array}{c}1.969 \\
(1.354)\end{array}$ & $\begin{array}{l}-4.296 * * * \\
(1.353)\end{array}$ \\
\hline Time & & $\begin{array}{c}0.223 \\
(0.217)\end{array}$ & $\begin{array}{c}0.260 \\
(0.206)\end{array}$ & & & & \\
\hline Time $^{2}$ & & & $\begin{array}{c}0.016 \\
(0.029)\end{array}$ & & & & \\
\hline Time $^{2}$ (before ban) & & & & $\begin{array}{l}-0.211 \\
(0.185)\end{array}$ & & & \\
\hline Time $^{2}$ (after ban) & & & & $\begin{array}{l}0.296 * * * \\
(0.087)\end{array}$ & & & \\
\hline Observations & $41,327,565$ & $41,327,565$ & $41,327,565$ & $41,327,565$ & $44,804,615$ & $41,361,673$ & $76,813,457$ \\
\hline II & $-687,477$ & $-687,476$ & $-687,476$ & $-687,476$ & $-710,705$ & $-690,322$ & $-1,295,048$ \\
\hline
\end{tabular}

Note: Author's estimates of the coefficients from Logit models of divorce risks. The unit of observation is marriage per quarter, and the outcome is an event of divorce within the given quarter. The quarters are shifted by one month so that the first quarter following the ban starts on the first day of the ban, March 1 2009. The time trend is centered on the first quarter following the ban. Dutch municipal register data. Standard errors in parentheses are clustered on time. 
Table A2: RD-DD estimates of the effect of flash divorce availability on quarterly divorce rate

\begin{tabular}{|c|c|c|c|c|c|}
\hline Variable & $\begin{array}{l}\text { RD couples } \\
\text { with children }\end{array}$ & $\begin{array}{l}\text { RD-DD } \\
\text { linear trend }\end{array}$ & $\begin{array}{l}\text { RD-DD } \\
\text { lin. spline }\end{array}$ & $\begin{array}{l}\text { RD-DD } \\
\text { quad. trend }\end{array}$ & $\begin{array}{c}\text { RD-DD } \\
\text { w/ time FE }\end{array}$ \\
\hline Flash * Married & $\begin{array}{l}12.381 * * * \\
(2.125)\end{array}$ & $\begin{array}{l}10.273 * * * \\
(4.011)\end{array}$ & $\begin{array}{l}10.810^{* * * *} \\
(3.820)\end{array}$ & $\begin{array}{l}10.984 * * * \\
(3.918)\end{array}$ & $\begin{array}{l}12.973 * * * \\
(3.658)\end{array}$ \\
\hline Married & & $\begin{array}{l}-59.100 * * * \\
(0.740)\end{array}$ & $\begin{array}{l}-60.158^{* * * *} \\
(1.183)\end{array}$ & $\begin{array}{c}-59.869 * * * \\
(1.004)\end{array}$ & $\begin{array}{l}-57.411 * * * \\
(0.999)\end{array}$ \\
\hline Flash & & $\begin{array}{l}1.761 \\
(2.909)\end{array}$ & $\begin{array}{l}1.410 \\
(2.618)\end{array}$ & $\begin{array}{l}1.329 \\
(2.641)\end{array}$ & \\
\hline Time & & $\begin{array}{c}0.557 \\
(0.347)\end{array}$ & & $\begin{array}{c}0.460 \\
(0.353)\end{array}$ & \\
\hline Time * Married & & $\begin{array}{l}-0.285 \\
(0.449)\end{array}$ & & $\begin{array}{l}-0.145 \\
(0.473)\end{array}$ & \\
\hline Time (before ban) & $\begin{array}{c}0.419 \\
(0.371)\end{array}$ & & $\begin{array}{l}0.00503 \\
(0.577)\end{array}$ & & \\
\hline Time (after ban) & $\begin{array}{c}0.182 \\
(0.269)\end{array}$ & & $\begin{array}{l}0.953 * * \\
(0.390)\end{array}$ & & \\
\hline Time (before ban) * Married & & & $\begin{array}{c}0.414 \\
(0.828)\end{array}$ & & \\
\hline Time (after ban) * Married & & & $\begin{array}{l}-0.764 \\
(0.497)\end{array}$ & & \\
\hline Time $^{2}$ & & & & $\begin{array}{l}-0.0603 \\
(0.050)\end{array}$ & \\
\hline Time $^{2} *$ Married & & & & $\begin{array}{r}0.0791 \\
(0.069)\end{array}$ & \\
\hline Second quarter & $\begin{array}{c}0.745 \\
(1.052)\end{array}$ & $\begin{array}{l}6.934 * * * \\
(1.890)\end{array}$ & $\begin{array}{l}7.485 * * * \\
(1.841)\end{array}$ & $\begin{array}{l}7.262 * * * \\
(1.783)\end{array}$ & \\
\hline Third quarter & $\begin{array}{l}4.109 * * * \\
(1.286)\end{array}$ & $\begin{array}{l}-0.136 \\
(1.696)\end{array}$ & $\begin{array}{c}0.274 \\
(1.347)\end{array}$ & $\begin{array}{c}0.345 \\
(1.370)\end{array}$ & \\
\hline Fourth quarter & $\begin{array}{c}0.633 \\
(1.197)\end{array}$ & $\begin{array}{l}8.091 * * * \\
(1.107)\end{array}$ & $\begin{array}{l}8.644 * * * \\
(1.510)\end{array}$ & $\begin{array}{l}8.681 * * * \\
(1.538)\end{array}$ & \\
\hline Second quarter $*$ Married & & $\begin{array}{l}-5.673 * * * \\
(1.903)\end{array}$ & $\begin{array}{l}-6.270 * * * \\
(2.007)\end{array}$ & $\begin{array}{l}-6.041 * * * \\
(1.900)\end{array}$ & \\
\hline Third quarter $*$ Married & & $\begin{array}{c}4.353^{*} \\
(2.332)\end{array}$ & $\begin{array}{c}3.825^{*} \\
(2.107)\end{array}$ & $\begin{array}{c}3.705^{*} \\
(2.054)\end{array}$ & \\
\hline Fourth quarter * Married & & $\begin{array}{l}-6.787 * * * \\
(1.140)\end{array}$ & $\begin{array}{l}-7.374 * * * \\
(1.683)\end{array}$ & $\begin{array}{l}-7.441 * * * \\
(1.669)\end{array}$ & \\
\hline Time Fixed Effects & $\mathrm{N}$ & $\mathrm{N}$ & $\mathrm{N}$ & $\mathrm{N}$ & $\mathrm{Y}$ \\
\hline $\begin{array}{l}\text { Observations } \\
\text { log likelihood }\end{array}$ & $\begin{array}{l}34,270,113 \\
-469,698\end{array}$ & $\begin{array}{l}46,11,866 \\
-791,900\end{array}$ & $\begin{array}{l}46,151,866 \\
-791,899\end{array}$ & $\begin{array}{l}46,151,866 \\
-791,898\end{array}$ & $\begin{array}{l}46,151866 \\
-791,895\end{array}$ \\
\hline
\end{tabular}

Note: Author's estimates of the coefficients from Logit models of union dissolution risks of married and de facto couples with children. The time trend is centered on the first quarter following the ban. Dutch municipal register data. Standard errors in parentheses are clustered on time. 
Table A3: Heterogeneity of the RD estimates

\begin{tabular}{|c|c|c|c|c|c|c|}
\hline \multirow[b]{2}{*}{ Variable } & \multicolumn{3}{|c|}{ Wage differentials } & \multicolumn{3}{|c|}{ Income terciles } \\
\hline & $€ 0-€ 5$ & $€ 5-€ 10$ & $€ 10$ and more & 1 & 2 & 3 \\
\hline \multirow[t]{2}{*}{ Flash } & $15.48 * * *$ & $10.53 * * *$ & $9.268 * * *$ & 3.967 & $15.43 * * *$ & $10.35 * *$ \\
\hline & $(1.158)$ & $(3.077)$ & $(3.275)$ & $(3.656)$ & $(1.185)$ & $(3.768)$ \\
\hline \multirow[t]{2}{*}{ Time (before ban) } & -0.033 & $-0.814 * *$ & 0.566 & -0.642 & $1.167 * * *$ & -0.753 \\
\hline & $(0.186)$ & $(0.347)$ & $(0.488)$ & $(0.626)$ & $(0.217)$ & $(0.743)$ \\
\hline \multirow[t]{2}{*}{ Time (after ban) } & -0.103 & -0.518 & 0.215 & -0.387 & $0.782 * * *$ & $-0.758 *$ \\
\hline & $(0.186)$ & $(0.428)$ & $(0.580)$ & $(0.607)$ & $(0.195)$ & $(0.395)$ \\
\hline \multirow[t]{2}{*}{ 2nd quarter } & $5.706 * * *$ & $4.016^{*}$ & -2.044 & 0.859 & $2.769 * * *$ & 0.255 \\
\hline & $(0.772)$ & $(2.169)$ & $(1.696)$ & $(1.950)$ & $(0.842)$ & $(1.499)$ \\
\hline \multirow[t]{2}{*}{ 3rd quarter } & $5.749 * * *$ & $7.386 * * *$ & 2.688 & 1.078 & $3.736 * * *$ & $6.332 * * *$ \\
\hline & $(0.800)$ & $(1.318)$ & $(2.082)$ & $(2.130)$ & $(0.974)$ & $(1.967)$ \\
\hline \multirow[t]{2}{*}{4 th quarter } & $1.375^{*}$ & $4.177 * *$ & 0.040 & $3.636^{*}$ & 1.045 & 0.175 \\
\hline & $(0.708)$ & $(1.696)$ & $(1.894)$ & $(2.117)$ & $(0.822)$ & $(1.813)$ \\
\hline Observations & $10,364,174$ & $4,688,984$ & $29,751,457$ & $14,726,264$ & $14,939,916$ & $15,119,546$ \\
\hline Log-likelihood & $-246,601$ & $-100,324$ & $-397,562$ & $-126,423$ & $-317,531$ & $-297,051$ \\
\hline
\end{tabular}


Table A3, cont'd

\begin{tabular}{|c|c|c|c|c|c|c|}
\hline \multirow[b]{2}{*}{ Variable } & \multicolumn{3}{|c|}{ Immigration background } & \multicolumn{3}{|c|}{ Urbanization } \\
\hline & Native & Blended & Immigrant & Index $\geq 3$ & Index $=2$ & Index $=1$ \\
\hline \multirow[t]{2}{*}{ Flash } & $12.40 * * *$ & $9.358 * * *$ & $8.778 * * *$ & $9.733 * * *$ & $13.10 * * *$ & $20.87 * * *$ \\
\hline & $(2.234)$ & $(2.075)$ & $(1.027)$ & $(1.921)$ & $(1.325)$ & $(7.112)$ \\
\hline \multirow[t]{2}{*}{ Time (before ban) } & 0.539 & -0.307 & $-0.767 * * *$ & -0.062 & $0.808 * * *$ & 1.676 \\
\hline & $(0.355)$ & $(0.386)$ & $(0.266)$ & $(0.312)$ & $(0.153)$ & $(1.123)$ \\
\hline \multirow[t]{2}{*}{ Time (after ban) } & 0.090 & 0.093 & $0.645^{* * *}$ & 0.058 & $0.523 * *$ & 0.184 \\
\hline & $(0.350)$ & $(0.294)$ & $(0.170)$ & $(0.321)$ & $(0.240)$ & $(0.741)$ \\
\hline \multirow[t]{2}{*}{ 2nd quarter } & 0.693 & $2.095 * * *$ & $6.627 * * *$ & 1.756 & -0.289 & 3.014 \\
\hline & $(1.251)$ & $(0.808)$ & $(0.854)$ & $(1.142)$ & $(1.527)$ & $(4.144)$ \\
\hline \multirow[t]{2}{*}{ 3rd quarter } & $3.921 * * *$ & $4.044 * * *$ & $8.863 * * *$ & $5.129 * * *$ & 1.319 & 5.969 \\
\hline & $(1.413)$ & $(1.092)$ & $(0.503)$ & $(0.960)$ & $(0.818)$ & $(5.049)$ \\
\hline \multirow[t]{2}{*}{ 4th quarter } & -1.083 & $6.816^{* * *}$ & $10.54 * * *$ & 1.420 & -0.148 & 1.808 \\
\hline & $(1.314)$ & $(1.025)$ & $(0.614)$ & (1.030) & $(0.800)$ & $(4.302)$ \\
\hline Observations & $37,645,001$ & $3,240,942$ & $3,918,672$ & $27,754,914$ & $10,825,472$ & $6,200,545$ \\
\hline Log-likelihood & $-577,511$ & $-92,134$ & $-77,353$ & $-508,218$ & $-155,339$ & $-85,169$ \\
\hline
\end{tabular}

Note: Author's estimates of the coefficients from Logit models of divorce risks. The unit of observation is marriage per quarter, and the outcome is an event of divorce within the given quarter. The quarters are shifted by one month so that the first quarter following the ban starts on the first day of the ban, March 1 2009. The time trend is centered on the first quarter following the ban. Dutch municipal register data. Standard errors in parentheses are clustered on time. 
Figure A1: Quarterly wedding incidence, unadjusted, 1995-2016

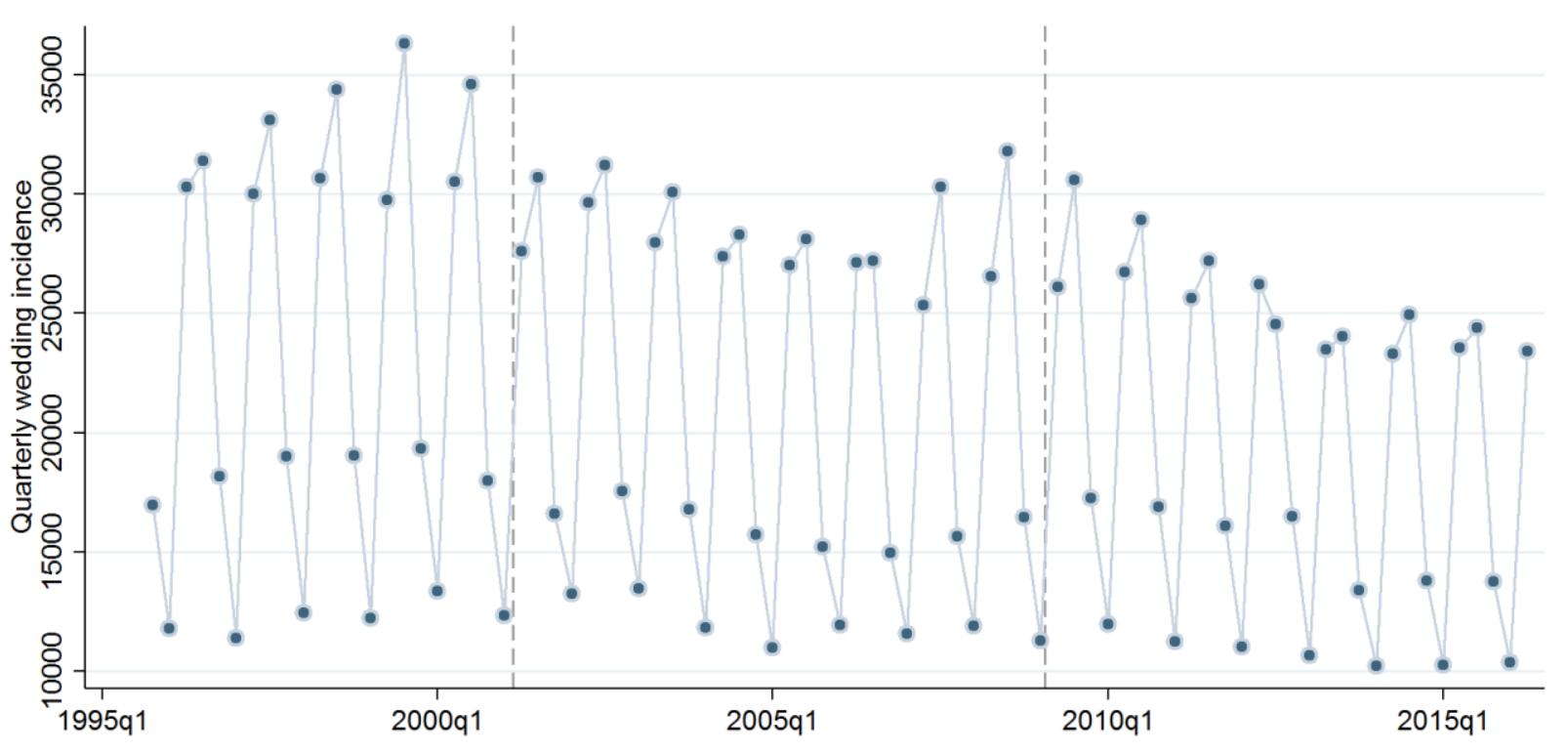

Note: Author's calculations of quarterly wedding incidence in the Netherlands between years 1995 and 2016. Vertical dashed lines represent the introduction and the ban of the flash divorce option. 


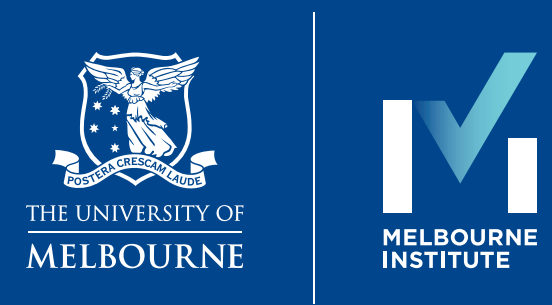

